\title{
KANUN ve KAZA
}

\section{Yazan: Hans Reichel}

\section{Çeviren: Ord. Prof.}

S. S. ANSAY

Merhum Hans Reichel'in 1915 de Zurich Fakültesinde Profesör iken neşrettiği Kanun ve Kaza (Gesetz und Richterspruch) adlı bu eseri önsözlinden de anlaşldı̆̆ tizere bir konferanstan meydana gelmiştir. Eșer intışar ettił̧i memleket için oldukça eski sayılabilir. Fakat garp hukukuna gec katılan błzler için o hukukun tarihine, tatbikatına müteallik her esere yeni diyebiliriz. Bu itibarla onbeş yl kadar önce dilimize çevrilen bu eseri bayat ve lïzumsuz telâkki etmiyoruz. Hususiyle eser tsviçre'de ve Isviçre hukukiyle de ilgili olarak yazıldığından faydalı oldugunu zannediyoruz. Reiche'in bu eseri hukuk edebiyatında çok defa anlan bir kitaptır. Eser, Eugen Huber e ithaf eđilmiştir.

Profesör Reichel 24 Şubat 1878.tarihinde dogmuştur. 1900 de hukuk ve felsefe doktorasını aymı zamanđa yapmıştır. 1911 de genç bir doçent olarak Zürich Fakültesine intisap etmiştir. 1920 de Hamburg Universitesine davet edilmiş, orada itibarh bir profesör olarak 1938 tarihine, yant hastalı̆̆ının zarurî kıldığı tekaütlüğune kadar kalmıștır.

Bazlarınca Reichel serbest hukuk cereyanın taraftarlarından sayılmıstır. Hakikatta Reichel stbjektif adaletin ve hissi yargınin aleyhindedir. Onun serbest hukuk cereyanina karşı noktai nazarı tercüme ettigjimiz bu yazllarında görülecektir. Daha sonra yazdığ1 1sviçre Medent Kanunu methal maddeleri hakkındaki satırlarda da bu mevzuu ele almıştır. Gene Reichel romanist olmakla beraber kendisini Roma hukukunun esłki, tarihi menbalarını bir arastırıcısı olarak saymamış, gözleri dajma ileriye müteveccih kalmıştır.

Profesör Reichel yalnız hususĩ hukuk ile değil usul hukuku ile de meşgul olmuştur. Kaziyei mahkeme ve haksız iktisap hakkunda kıymetli yazılar yazdığ gibi jâva edilemfyen iddialar adlı bir eseri daha vardir.

Kendisi 9 Nisan 1939 da Hamburg civamnda Rahlstedt'de 61 yaşlarinda vefat etmiştir. Bu vesile ile kendisini hürmetle anarı. 


\section{ठ N S $\boldsymbol{~} \mathbf{Z}$}

Hâkimin kanuna karşı durumu, yani hâkimin kanuna bağlıh̆ğın muhtevası ve hududu son zamanda çok bahsedilen bir mesele olmuştur. Hukuk kaynakları nazariyesi ve hukuk tatbikatı metodu hakkındaki taharriler ve yaymlar hali hazir hukuk münakaşalarmnda geniş bir yer almaktadır. Serbest hukuk hareketi denilen hareket, fikrî cereyanların çok daha büyük ve daha şümullü kompleksi içinde ancak bir kısım hâdisedir. Bu cereyanlam doğru anlamak, onlar hakkinda tam tartılı olarak bìr muitalâa dermeyan edebilmek için her seyden önce bu șeyin tarihî menşeini takdir zaruridir. Hakikat halde kültür tarihinin bir parçası bahis konusudur. Böyle bir tarihi nazar ircaundan, böyle bir tarihi görüş iktisap ettikten sonradir ki fikir muicadelesi dalgalarında sağlam zemin tutabilmek ve zatî kanaat husulüne temel kurabilmek için kâfi derecede serbest ve geniş bir riuyete sahip olumaz. Aşağıdaki izahlar bu hususta biraz yardımda bulunmak içindir. tzahlarımızın bir tarihi ve bir de doğmatik iki baş kusma aymlmasımm sebebi bu sözlerden kendiliğinden anlaşlir.

$\mathrm{Bu}$ tetkik tatbikatçlar önünde verilmiş bir konferanstan meydana gelmiştir. Bu itibarla evvel emirde tatbikatçlara müteveccihtir. Bunun içinđir ki mümkün olduğu kadar şümullü bir çok açı misaller vermeğe çahşılmıştır. Surf muicerret izahlarla tatbikatçılara hizmet edilmez.

Eserler gösterilirken bir seçim ile iktifa edilmiştir. Bașka eserler için şunlara bakılabilir. Yung, Das Problem des natürlichen Rechts 1912 s. 330; Heck, Das Problem der Rechtsgewinnung, 1912, Anhang I, Heck, Gesetzesauslegung und Interesseujurisprudenz, 1914, s. 1; Pattai, Der Kanpf um die Rechtswissenschaft, Wien 1913.

Zürich, yaz mevsimi 1914 


\title{
BIRINCI KISIM
}

\section{TARM BAKIMINDAN}

\author{
Ön miilâhazalar
}

Hukuk âlemindeki bugïnün hareketleri bir aksülâmel tezahürü, bị savaş ve müdafaa hareketidir. Bu hareket 19 uncu asırda hükmüferma olan bir siyasî sisteme ve onunla murtabit hukukî akideye karşı bir isyan gibi kendini gösterir. Bu sistem devletin hukuk imalindeki monopolüne müstenit kanun mutlakiyeti denilen sistemdỉr (1). Bu sistemin hukukî noktai nazardan ifađe ettiği şey, kodifikasyon prensibi yahut her şeyin kanundan beklenmesi akidesi (doğması - Allgesetzlichkeitsdogma), yani boşluktan âri kanunun yalnız başına hükümranlığ ve her şeye kifayeti nazariyesidir.

Bu suretle aşağıdaki tarihi izahatın krokisi çizilmiş oluyor. Evvel emirde kanun mutlakiyetinin tarihi öncỉlerini, yani prenslerin istipdadinı kısaca aydınlattıktan sonra ( $I$ inci fasıl) kanun mutlakiyetçiliğinin menbain, mahiyetini ve neticelerini olduğu gibi gözden geçireceğiz (II nci fasil). Ondan sonra o sisteme karşı tedricen zarurî olarak baş gösteren umumî kültür hareketlerini göstereceğiz (III üncü fasl). Bundan sonra meşgul olacağımı kanunun kiilli kudretine karşl hassaten hukuk ilmi sahasindaki mukabil hareket (IV) o umumî zaman ve fikir cereyanlar1nun bir inikâsı ve neticesidir. Fakat bu mukabil hareket de daha ileride göreceğimiz üzere heđefini aşmağa temayül göstermiştir. Bu itibarla tehlikeyi haber veren ve makuliyet ihtar eden bir tenkide maruz kalmiştır (V). Son fasıl olarak da eskilerin ve yenilerin birleşmek tizere bulundukları zannedilen mutavassit hatta isaret olunacaktır.

\section{BIRINCI FASIL}

\section{Devlęt mutlakiyeti}

Mutlakiyet sözünü işittiğimiz zaman her şeyden önce mutlakiyetçi zabıta devletini, bilhassa prenslerin mutlakiyetini, az çok tenevvür etmiş despotizmi hatırlamak mutadımızdır. Bu despotizmin en açlk ve sempatik mümessilleri olarak karşımıza Fredirik II ve Josef II çlkmaktadır.

(1) Bak. Bartsch in der Zentenarsechrift zum A. B. G, B, 1911, Bd, I s, 676. 
1. Mutlak devletin siyaşi ve âmme hukuku bakımından remzini, devlet benim (l'Etat e'estmoi; suprema lex regis voluntas; qui veult le roi, si veult la loi) sözleri teşkil eder. Prens her hususta her şey idi. Devlet içinde bütiin bașkalar, hatta memurlar tebaa ediler. Tamamiyle gayri müstakil olan memurlar zỉmresi içinde hâkim, müstakil bir katagori teşkil etmezdi. Hâkim memurdu ve sadece memur idi. Hâkimin istiklâlinin lâfı bile yoktu. Hâkim de hükümdarın takdiriyle bütün öbür memuxlar gibi tayin ve azldeilebilirdi. Fredirik II gibi münevver ve zeki bir hüküimdar bile bu noktai nazarn korkulu misallerini vermiştir.

2. Bu mutlakiyet fikri, bu pederane hacir, hâkimin kanun ile münasebetinde de barizdi. Kanun, memleket beylerinin, kayitsı ve şartsız itrat edilmesi borçlu bulunulan iradesi idi $\left(1^{*}\right)$. Hâkim, ancak memieket reisinin kanunda vücut bulmuş iradesinin tenfiz memuru idi. Kendiliğinden karar alma salâhiyetini haiz değildi. Kanun ve talimatlar ona, luizumlu olan her seyi söylemiş bulunuyordu. Bizim bugïn tefsir dediğimiz şey hükümdarm kendisi olan kanun vazaıın ne kasdettiğini ve ne arzu eylediğini arașturmaktan ibanetti. Hâkim, kanunun manasinda tereddüt ederse yahut onda bir boşluk bulunduğu zehabında olursa hükümdara yahut vekiline müracaat eder, onun otantik fikrini ve kararmi ahrd1 (2).

3. Bu telakkinin vaktiyle ilim sahasinda nasıl kök attı̆̆ hakkında Beccaria'nın cinayet ve cezalara dair, diğer noktalarında müterakki ve hürriyetperver olan eseri bizi hususî bi vuzuh ile aydınlatmaktadı (3). Orada deniliyor ki hâkim için kanunu tofsir salâhiyeti yoktur. Hâkim böyle bir salâhiyetle kanun vazıl olmus olur. Kanunun ruhunu, istiģare mevzuu yapmak pek tehlikeli bir şeydir; bu, hâkime fazla bir hareket sahası verir. En iyi kanun tefsire en az yer verendir. Kanun ne kadar tefsire müsait olursa o kadar fazla cinayetler işlenir. Kanunun kelimelerini sıkı sıkıya takipten đoğabilecek olan zarar, tefsir ile çıkacak mazarrattan ehvendir; bir kanunun despotizmine, bir alay hâkimlerin keyfi hâkimiyetinden daha çok tahammül edilebilir. Hatta ilim, tehlikelidir; çünkü ilim bir fikri başka bir fikre kar\$l koyar ve bu suretle huzurumuz muhtel olur. "Kanunlar, bir ilim mevzuu olmayan millet, bahtiyar millettir".

4. Işbu mutlak surette itaat ruhunun, gerek fert ve gerek hâkim hakkındaki hayırhahane hacrin en mühim teşrii âbidesi, Prusya-

(1*) Bayer, L. R. L., \& 3: "Bir kanun, umumun iyiliğine taalluk eden jşlerde tebaaya, hükümdarca verllmis bir emirdir".

(2) Bak. Spiegel, gesctz und Recht 1913, s. 64, 100. ff: (Über das reféré Iegislatif). Uber den Codex Theresianus hak. Wurzel, Das juristische Denken, 1904, s. 21.

(3) Almancast Esselborn tarafmdan 1905. 
nın 1794 tarihli umumî memleket hukukudur. Bu hukuk diğer noktalardan büyük Fredirik'in biraktığı kültïr itibariyle en büyük metrukâtı ve on sekizinci yüz yrlın en büyük teşrî̀ hizmetidir. İsabetli, makul ve bir çok noktalarda muhteva itibariyle pek müterakki bir kanundur; hakhiyle sevilmiş ve övülmüßstür. Ôyle sebepsiz tam yüz yll itibarda kalabilmiş değildir. Fakat bu kanunun iri hacmi gösterir ki müstakil, mesuliyeti üzerlerine alır hâkimleri meydana getirmeğe salih ve muayyen bir kanun değildi. Baska hususlarda hürmete şayan olan ve ģok medhedilmiş bulunan eski Prosya itaat ruhu, Fredirikvari onbaşı değneği her sahifesinde göriilür. Yanlıs yola gitmemesi için, müstakilen karar ittihazı, her veçhile hâkimden nezedilmiştir; her şey en ufağına varıncaya kadar tasrih edilmistir. Bu suretle tereddiide meydan vermemek istenmiştir. Fakat bilfiil bir tereddüt ortaya çıkarsa zatî takdire müracaat edilemiyecek veya cinayet mahkemesi nizamnamesi (Halsgerichts ordnung) nun emrettiği üzere hukuk mütehassıslamnı reyi alıamıyacaktır; bilâkis hâkim, kanun komisyonuna başvuracak, o da kanunun tefsirini ona gösterecektir (4). Hülâsa, Prusya umumî memleket hukuku mutlakiyetin en muhteşem bir teşrii eseridir. Bu hükümet seklinin faikiyetleri ve fakat zaafları da, bu kanunda olduğu kadar hiç bir âbide de bu kadar klâsik okunamaz.

5. Mutlakiyetin klâsik teşrii eseri, Prusya teşriidir. Fakat mutlakiyetin klâsik memleketi 1848 martından önceki Avusturyadur; Metternich'in memleketidir. "Mart öncesi memur mafevkine itaat etmekten, hoşa gitmekten başka hiç bir ideale sahip değildi. Harekâtımın bütün teferruatina kadar noktası noktasına tayin edilmiş olmasın bir engel değil, kendi faaliyeti için gayet makbul bir kolaylık sayardı. Bu itibarla her hangi bir tereddüde düssse talimat almak için "saraya" müracaat ederdi. Çünkü bahis mevzuu olan şey, imparatora hizmet idi ve bundan dolayı memurun bizzat en iyi surette işi hal ve tesviye eden reyi düstur değildi. - memur böyle bir reyi, ancak bu bapta kendisine bir sual teveccüh ettiği zaman haiz idi -, diistur, en yüksek makama has olan rey idi (5). Kanun Monarch'ın iradesi idi. Kanunu tenkide cüret eden kimse, haşmetmeabı tahkir tehlikesine düşerdi (6).

İşbu siyasî temel telakki, 19 uncu yüz ylın ortașına kadar hâkim telakki idi. Yüz yıllarca süren bu eski telakkiden mütevellit tesirlerin

(4) Bak. Einl. $\$ \$ 6,47$, 50. Hedemann in, Werden und Wachsen im burgerlichen Recht 1913, 8 bak.

(5) Spiegel, s. 20.

(6) Pattai, Kampf um die Rechtswissenschaft, 1913, s. 15. 
bugüne kadar ulaşmamış olması bir mucize oiurdu. $\mathrm{Bu}$ tesirierden en mühimi, kanunda maddileşmiş iradesi, her memur ve her hâkim için kayitsiz, şartsız muta' olan bir kanun koyucu hakkındaki derin kökleşmiş telakkidir. Bu telakkide ne kadar jyi ve ehemmiyetli taraflar bulunduğunu kim inkâr etmek istemiştir? Fakat bu, işin ve zamanm dururúuna uygun mudur, bilâkis kötï bir sathiliği ve tehlikeli hatalar tazammun etmez mi meselesi şüphesiz başka bir meseledir.

\section{IKINCI FASIL}

\section{Kanun mutiakiyeti}

Geçen zamanların prensler mutlakiyeti hakkında çok seyler söylenebilir. Şüphesiz tetkikimiz bu mutlakiyet hakkında doğrụdan doğruya çok bir sey vermeyecektir. 19 uncu yüz yll bilhassa 1948 yll prensier mutlakiyetini attı. Artık otoratik prenslerin mutlakiyetini değil, daha ziyade modern meşrutî kanun mutlakiyetini nazara almağa mecburuz. Sonraki on yillarin kanun mutlakiyeti, prenslik mutlakiyeti ile pek az ilgili olup hatta esas itibarile onun sert bir inkârını tazammun eder. Kanunun mutlak kudreti sistemi, prenslik mutlakiyetine karş müdafaa vaziyetinde bulunan ve ona mezarnn kazmış olan hareketin, yani merutî liberalizmin doğrudan doğruya bir mevlududur. Fikat bu sistem son fikri köklerini, 18 inci yüz ylhn devlet felsefesinde, tillhassa Montesquieu'nun kuvvetleri tefrik nazariyesinde bulur.

1. Kanunlamn ruhu adl eserinin en meshur bir kısminda (kitap 11, kısım 6) Montesquieu su nazariyeyi serdeder. (7): Her devlette esas itibariyle üç kuvvet vardır: Kanun koyucu (teşriî), icracl ve kazacı. Vatandaşın hürriyeti başı için bu üç kuvvet, yalnız nazariyat itibariyle değil, amelî noktadan da sarih ve daimî surette ayrı bulunmak lâzımdır. Bu kuvvetlerden birinin öbürünün sahasına her hangi bir müdahalesine ih́timamla meydan verilmemelidir. Kanun koyma kuvveti, kanunlar çkarmakla, yani umum için lüzum ifade eden mücerret kaideler koymakla mükelleftir. Bu kanunlara herkes, bilhassa icra mercileri de uymağa mecburdur. Bu kuvvet hukuk yapar, fakat hukuku hüküm etmez; emirlerini de bizzat icra etmez. Infaz, icraya ait bir istir, icra da kanun koyma sahasına her hangi bir müdahaleden ve keza kaza sahasına her türlü tesir yapmaktan kaçınmakla mükelleftir. Nihayet kaza, kanunun mün-

(7) Bu nazariye bizzat Montesquieu'dan mı çlkmaktadır meselesi bu bahsi ilgilendirmez. 
ferit hâdiselere tatbiki, kanunun mücerret emirlerinin konkre hayat münasebetleri bakımmndan konkre bir hükme tahvildir. Hâkim, kanunun canlanmış sesidir. $O$, kanunun mücerret halde emrettiği şeyi müşahhas olarak ifade eder. Hukuk yaratmak ise hâkimin salâhyeti dahilinde değildir. Hâkim, böyle bir sey yaptığı takdirde kanun koyma kuvvetine ait bir işe karışmıs olur. Bu ise idare memurlarnna taalluk etmediği kadar hâkime de ait değildị:

18 inci yüz yllda ortaya konan ve nazarî surette ilân edilen şu doktrin (8), amelî tatbikatım başluca 19 uncu yüz yll ortalamnda (1848) görmüş̧ür. Modern kanunu esasiye bağh, mesrutî devlet (Verfassungsstaat), kuvvetlerin bölünmesi nazariyesini hakikat haline sokmağı üzerine aldı. Kanun koymağa, hükiłmdar, parlâmento salâhiyetlidir; iera, müstakil idarî organlar teşkil edilmediği takdirde münferiden hükümdara, yahut onun mesul nazanna aittir; kaza kuvveti ise müstakil, yani yalnız kanuna tâbi hâkim marifeti ile kullanılır; müstakil hâkimier; çünkü bunlar ancak kanuna tabidirler. Fakat bir yandan da gayri mïstakil hâkimler; çüinkì onlar kanuna, doğrudan doğruya ve kayıtsız, şartslz bağhdirlar ve anayasaya tevfikan vücude getirilen mektup kanun onun resmi faaliyetinin biricik düsturudur. Kanun devlet iradesinin en yüksek ifadesidir; hukuk íse devletin iradesidir. Bu suretle kanun devlet içinde hakikî ve biricik hükümrandır. (Nomokrasinin, kanun devletinin ideali).

2. Bu doktrin, mutlakiyet aleyhtar 'olmak istiyordu. Hakikatta da böyle mi idiği şüphelidir. Prenslerin mutlakiyeti tabî̂ kırılmıştı; fakat onun yerine meşrutî kanunun hudutsuz mutlak kudreti kaim olmuştu. Kral ölmüştür; yaşasın kral (Le roi est mort; vive le roi!) $\mathrm{Bu}$ doktrinin hakikatta göründüğü kadar ahrarane olduğu keyfiyeti de su götürür. Șïhesiz meşrutî kanun, sarayın keyfinden azadeliği ifade ve fert için kiymetli bir himaye vasıtası teşkil eder. Fakat kanunun sadece şeklinde her hangi haksız bir tazyika, zulme karşı maddî bir garantị mevcut olduğu iddiası tarihen teeyyüt etmiş değildir. Bizim sadece eski ve yeni zamanın bazı demokrasilerini düşünmemiz bir ekseriyetin tiranlı̆̆ı, bir müstebidin keyfî hükümranlı̆̆ kadar ezici olduğunu görmemize kâfidir.

Fakat ferdin hürriyeti burayı alâkadar etmez. Biz daha ziyade burada hâkimin serbestliği neden ibaret olduğu meselesini ele alıyoruz. $\mathrm{Bu}$

(8) Unlla poena sine lege kaidesi de aydinlanma devri felsefesine medyundur, asıl menşei degilsede siyasi kanaat kuvveti oradadı. Bilhassa Anselm Feuerbash bu kaideyi kati bir enerji ile mldafaa etmiştir; bak. Rumpf D. R. Z. 1913, 773. 
hürriyet hakkında basit burjuva liberalizminin (spiessbürgerliche Liberalismus) hiç bir fikri yoktu. Süüphesiz hâkim kabine adaletinin ve saray emirnamelerinin tazyikinden kurtulmuştur. Idarî mercilere karşı serbesttir; hatta hâkime, münferit ihtilâflarda idarî mercilerin emirlerini hükümsüz saymak salâhiyeti bile verilmiştir. Fakat hâkimin serbestliği bundan ibaret olamaz. Hâkim, ancak kendisine itimat edilir, vazife ve mesuliyet hissini faal kllabileceği bir takdir sahasi verilirse serbesttir. Liberalizm ise bu noktada tamamen red durumunda kalmıştır; hatta bazan, müstebit zabita devletinden daha çok hasis davranmıştır. Yeni vücut bulan teşrii organlar, henüz pek zor elde edebildikleri haklara kıskançlıkla sarlarak kendi salâhiyetlerinden ifratla istifade ettiler. Her zुey ve herkes kanunun ağına yakalanmıştı; mümkün olduğu kadar hâkimin hareket serbéstliği nezi edilmiştir; korku ve itimatsızlık içinde onun takdir hakkma meydan verilmiyordu. En karanllk despotizm zamanlarında 19 uncu yılın serbest meşrutî devletinde olduğu kadar hâkimin serbest takdirine karş böyle bir gïvensizlik hemen hemen cari olmamış idi. "Ey hâkim serbestsin; ancak milyonlarca paragraflara riayete mecbursun" (9).

Liberalizmin hâkimliğe karşı bu kadar müsaadesiz davranması hahikaten güç anlaşlur bir şeydir. Çïnkü devlet içinde, vatandaşın hïrriyetini, kendi elinde mahfuz tutacak bir fert var ise o da her cihetten mistakil olan hâkimđir. Bu ítimatsızlık hakikatta ancak tarihî yönden anlaşlabilir. Hâkim değil, hâkimin şahsındaki maaşlı devlet memuru şïpheli idi; bu memur ki, buitün adlî istiklâline rağmen yukarıđan gelecek tesirlere karşı daima mukavemet üzere kalacağı hakkında kendisine kâfi derecede şahsan itimat edilemiyordu. Hâkimin değil, memurun nazara alındığın, aynı zamanda Fransız - Ingiliz jüri mahkemesinin rağbet bulması ve Söoffenlerin kabulüne taraftar olumması açlk olarak gösterir. Bugün dahi jüri mahkemelerine karşı bir çok yerlerde verilen kıymet (10), zannolunduğu gibi jürilerin hukukçu olmamasından değil, belki mlinhasıran memur olmamalarından nâşidir.

3. Liberalist devlet hukukunun gösterdiğimiz temel telâkkisinden, teşri' organına enerjik bir iddia çlktı. Buna kodifikasyon prensibi denile-

(9) Beradt, Der Richter, s. 11.

(10) Bu kıymet atfı, ancak siyasî mülahazalara istinat edebllir. Filhakika jüri mahkemesinin hukukan faydasızlı̆̆ lizerinde meslektaşlar müttefiktirler. (bak. A. Hellwig, Psychologie der Urteilsfindung, 1914, 38). Fakat siyasi delillerde pamuk ipligi mesabesindedir. Bak. Meili nun sert tenkidine, Der Zivil - und strafprozess des Kantons Zürich I (1882), s. 14 ff. 
gelmektedir. $\mathrm{Bu}$, teşri' tekniğini mümkün olduğu kadar tam kılmak, hayat tezahürlerinden akla gelebilen ne varsa hepsini kanun maddeleri içine sokmak, fakat bütün başka mümkün olan hukuk kaynaklarından, bilhassa örf ve âdet hukukundan hayat bağlamn kesmek demektir. Böylece - tarihî mektep marifetiyle onlarca yl geriye atılmış olan, fakat polis devleti yolunda oryante edilen tabiî hukuk fikir cereyanlarına açıça tekrar bağlanma suretinde - ihatalı, mümkïn olduğu kadar geniş mevadd tamaminda diuzenleyici teşri' eserlerine yeniden bir mevki verildi. $\mathrm{Bu}$ hamlenin iyi ve büyüls șeyler meydana getirdiğini kimse inkâr edemez. 19 uncu yüz yılm ikinci yarısındaki büyük teşri' başarlamm, Alman umumî ticaret kanunundan tutunuz da medenî kanuna, Avusturya hukuk usulï kanununa ve tsviçre medenî kanununa kadar bütün verimlerî biz buna medyunuz.

4. Fakat hâkim hakkında da cidđî bir söz söylemek lâzım geliyordu. Modern meşrutiyetçilik, hâkimin mümkün olduğu kadar yazilı kanuna dar surette bağlı̆̆ı̆ı parolasını veriyordu. Ve hakikatta ufak, fakat miiesssir ruhî vasıtalar sayesinde hâkimin işbu kanuna sadakatini temin etmeği bilmis idi. Bunlardan mühim olan ikisi şunlardır:

a) Birkere gerekçe mecburiyeti. Modern meşrutî devlet, hâkimin kararlarm (hic olmazsa en mühimlerini) esbabı mucibeye iktiran ettirmesi, bunların hüküm sebeplerini, "motifleri" ihtiva etmesi lâzım geldiği esasını koymuştu. Hâkimin, kanundan çıkardığı hükmïniu yazı ile (11) gerckçelemek, yani onun kanun ile ahenkli olmasın meşruleştirmek hususundaki işbu mecburiyette, hâkimin kanuna karşı büyửk mikyasta müessir psikolojik bağlllığı mündemiçtir. Gerekçe mecburiyetinin hakikî gayesi bu idi. Bir Italyan psikoloğu bunu ikna edici surette izah etmiştir (12). Hükmün mucip sebepleri, taraflar ikna etmekten ziyade hâkimin kanuna sadakatini kontrol etmek, mevhum bir hakkaniyet veya keyif kazasina meydan vermemek gayesini de ihtiva eder.

Hâkimi daima kanuna müracaat ettirmck için bu gerekçe mecburiyetinin ne kadar elverişli ve lüzumlu olduğuna, malûm oldığu üzere bir gerekçeye muhtaç olmayan jüri kazası açı bir hüecettir. Jüriler kararlarınu, mucip sebeplere iktiran ettirmek mecbuiyetinde olsalardi fiiliyatta vaki olduğu üzere çok defa kanun ve hukuk üzerine çlkmazlardı (13).

(11) tsviçrenin bazı kantonlam, mesela Zürich kantonu, sözlli gerekçeyi de tanrlar; çunkü bunlar açık müzakereyı kabul etmişlerdir. Bu tarzdan elde edilen neticeler gayri musait degildirler.

(12) Vacca, sulla importanza psicologica della motivazione nelle sentenze dei giudici, 1912, 362 ve sonrakiler.

(13) Bu bapta Isabetli söza Henri Bergsson söyler, l’Opinion, 1903, 501. 
b) Öbüriu de kanunî yollara müracaattır (yeniden tetkik, yukarı dereceye götürme, nakz yolu). Kanunî bir hüküm hị̧ veya doğru tatbik edilmezse (violation de la loi) kanunî yola müracaat olunabilir. Bu tetkiki icra için yukar bir derece teşkil olunmuştur (Alman Reich mahkemesi, en yüksek mahkeme divanl, federal mahkeme, kasasyon mahkemesi), bunların azası yalnuz faziletçe değil, yaşlan bakımından da sıkı bir seçim usulüne tabidir ve aslen, hasseten vazifeleri kanuna uygunluk kaziyesinin yolunda cvereyan ettiğine nezarettir. Merkezi temyiz mercii - teşekkỉiui ve maksadı icabınca - kanunun hakikî muhafızıdır. Her hâkim, hemen hemen daima hükmünün nakz edilmemesini arzu eder. Fakat böyle isteyince hükmünü kanun ile yahut daha ziyade yukarı mahkemenin kanuna verdiği tefsir ile ahenk halinde bulunđurması lâzımdır.

5. Almanyada ve Avusturyada hukuk tatbikat, ona tahmil edilen mecburiyete muhalefetsiz, hatta sıkintısız uyarık göstermiştir. Mutlak devletten beri memur itaati içinde terbiye edilmiş olạn hâkim, o zamana kadar idarî iradeye ifa ettiği hürmeti kanuni iradeye devrettj. Hâkim, kanuna, bir vahiy gibi bakıyordu. Kanuna karş, eski Luter'ciliğin mukaddes kitaba karşı aldığı sıkı bir ortodoksi ile vaziyet alıyordu (14).

Hukuk tatbikatı kayıtsız ve gartsız mutavaat halinde idi; fakat hiç olmazsa hukuk ilmi, hâkimin işbu siddetli ve belki de pek şiddetli olan kanuna bağlılığına karşı tereddüdünü lzhar etmedi mi? tlim - kezalik hukuk ilmi - ve onun doktrini şüphesiz hürdür.

Burada kayda şayan bir müşahedede bulunuyoruz. Eski tarihçi hukuk mektebi, mektup kanunun hürmetkârı değildi. Bu mektep bilâkis örf ve âdet hukukunun organik inkişafına taabbüt ediyor, takninden kaçınıor ve hukukun ilim ile tekâmülï̈nü heyecanla istiyordu. Savigny'nin kanun vez'ı ve hukuk ilmi hakkında zamanımızı (1814) vazifesine dair olan yazısını düşünelim; orada, o vakit yeni meydana gelmiş olan, Alman devletleri hususi medenî kanunları hakında, pek cesaretle (hakikî gayeyi çok aşar surette) tenkitte buhunulmuş idi. Keza Puchta'nun örf ve âdet hukuku üzerine yazdığı kılâsik kitabını da hatırlayalım. Oorf ve âdet hukuku tarihçi mektebin hakikî sevimli çocuğu idi.

Fakat tarihçi mektep kendine ve idealine sadakatsizlik gösterdi. Ananevî hukukun - yeni zamana göre bir usus modernus meydana getirmek manasında - zamana uygun surette tekâmüliüne çalışacak yerde

(14). Bak; Weber, Die philosophische Scholastik des deutschen Protestanismus im Zeitalter der Orthodoxie 1913. Kantun ortodokslugu ile yazılmıs a iman (Schriftglaubigkeit) arasındaki kerabet hakkında başlica 1913. Radbruch'un şu yazısi jkne edicidir: Archiv ftir Soztalwissenschaf, 1906, 366. Bak. v. Aster; Münchener Allg. Zeitung $1908,124$. 
kendini eski döküntiljere (Mikrologie) verdi. Sararmıs metinleri ortaya attı, çoktan gömülmüş yabancı bir kültürün krmk, dökük bakayasını, 19 uncu yüz yl Alman hukuk hayatı için düstur olması yolunda garip isteklerde buiundu. Tarihçi hukuk mektebinin yaptığı kadar gayri tarihi bir telâkki tarzını hukuk tarihi henüz görmemiștir. Böyle bir garabeti ancak böyle bir ümitsiz doktrinci yapabilirdi (15).

Tarihçi mektebin 19 uncu yüz yll sonuna kadar hüküm sürdüğ̈ iddia edilmektedir. Bu iddia yanlıs bir anlaysştır. Halis ve hakiki tarihçi mektep değil, ondan doğan, isbatiyeci hukuk mektebi son on yllarda üstün bir mevki tutmustu. Bu mektebe isbatiyeci (positivistisch) adı veriyorum. Bu tesmiyeyi, yalnız 19 uncu yüz ylln son on yllarnnda büyük bir intişara mazhar olan ve kendisiyle işbu hukuk nazariyesi arasında her halde bazı mertebe sthriyet bulunan aynı namdaki felsefi fikir hareketine işaret için değil, belki ve her seyden önce bu mektebin gûya hukukta surf miskset (positif) $\mathbf{e}$, yani vazlh ve muayyen mektup kanuna (sinnifällig geschrielene) avdeti doğru bulmasindan dolayı da yapıyorum.

$\mathrm{Bu}$ tarihçi mektebin akidesi (doğması) bütün hukukun müsbetiyeti idi. Bu mektep, müsbet hukuktan başka hukuk olmadığını talim ediyordu. Müsbet hukuk da ancak dcvletin hukuk o’arak ilân ve emrettiği geydir (16). Bu ilânın şekli kanundur. Bunun yanında bir de örf ve âdet hukukunun varlığı her ne kadar nazariyatça kabul ediliyor idiyse de tatbikatta ekseriya tamamiyle unutuluyordu. Her mesele hakkanda ne ve neye dair olursa olsun kanun, diustur olacak bir cevabi intiva eder. Kanun boşluktan âridir. Hiç bir hukukî mesele yoktur ki onun hakkında kanun açı bir cevap vermis olmasın. Hukuk ilminin vazifesi - bu ilim hukuk tarihi olmadıkça hatta yegâne vazifesi - kanunun manasinı yahut denildiği üzere kanun koyanın iradesini araştrmaktır. Neticenin âdilâne olması ve maksada uygunluğu meselcsi hâkimin vazifesi değildir; Hukukçuluk politika değildir. Hâkim, siyasî mülâhazaları kanun koyana, bilhassa parlâmentoya bırakmakla mükelleftir. Hukukçu mevzu kanundan ayrılamaz. Hukuk hakkındaki fikir ve akıl oyunları semeresiz metafizike götürür; felsefe zamanları geçmiştir ve tabiî hukuk hamdolsun mağlûp olmuştur.

Bu istikametin ilmi zirvesini Windscheid'in pandekt kitabl, Binding-

(15) Bu bapta Lanrsberg, Geschichte der deutschen Rechtswissenschaft, III, II, 222.

(16) Imperativentheorie denilen nazariye bu noktai nazaria alakalı değildir. Bak. Reichel, Zeitschriff für Rechtsphilosophie, 1914, 397. 
in ceza hukuku kitabı (17) ve Bergbohm'un Jurisprodansı ve hukuk felsefesi hakkınđaki bilgi nazariyesi ve kuritiğini havi kitabı (1896) temsil ederler. Bunlar parlak ve bir çok noktadan boy ölçüşülemiyecek hizmetler, mana ve ince fikirlerle doludur; Alman hukukunun iftihar edebileceği eserlerdir; fakat esas istikametinde ve sisteminde tamamiyle, kendilerini meydana getiren zamanin pozitivist fikrinin çocuklardir.

Daha 1847 de cesur bir mütefekkirin derin bir itminanslzlıkla aleyhinde bulunduğu, bu pozitivist hukuk ilmi idj. Bu mütefekkir bunun, ilim olarak karakter ve klymetini reddediyordu (18). Kirchmann'ın bir taraflılıklan ve mübalâğaları bu mahiyetiyle derhal anlașıldı ve takbih olundu (19). Fakat kitabının ihtiva ettiği hak ve hakikat o vakit tetkik olunmamış ve belki de tetkik edilmek istenmemişti. Bu suretle o, çö'de bir vaiz gibi kaldr.

6. Winscheid'in ismi bir istitrada vesile oldu.

Windscheid romanist idi. Keza Avusturyalı namidar hukukçu, mümtaz Josef Unger de romanist iđi. tsviçrenin şöhretli hukukçularr yllarca romanist idi. Romanist ilim hatta Fransaya da el attı. Biraz önce kısaca tasvir ettiğimiz fikir cereyanında Roma hukukunun - yabut hiç o'mazsa kendi hususiyeti icabı takip edilmesi lâzım gelen nevi ve tarzinin - bir hissesi olup olmadığ suali ortaya attlursa taaccuip etmemelidir. Modern polemikçiler bu suale müsbet cevap vermişlerdir. Windscheid'e ait olan terkip jurisprodansı (Konstruktionsjurisprudenz) bazan hemen Pandektologie olarak tavsif edilmis ve modern mukabil cereyan, "Roma cereyanindan aymlma = Los - von - Rom - Bewegung" olarak karakterize edilmiştir. Hatta bir müellif serbest hukuk hareketinin, romanizmin mefhum riyaziyeciliğine karşı bir Cermen aksïlâmeli olduğu iddiasiyle ortaya atılmiştır (20).

Bu telâkkiye ne kadar enerji ile karş gelinse azdır. Roma hukuku ve bilhassa klâsik Roma hukukçulamnın eserieri, skolastik; terkibi, construktionell, mefhum hesabiliği yahut bu gibi tabirlerle ifade etmek istenenden tamamen başka şeylerdir. Bilâkis: Roma hukuk tarihi bize, bugïn de hayran bir takdir ile baktı̆̆ımız bir hâkim kral verdi: Pretor. Fakat

(17) Binding'de serbestçe bir kanun tefsiri nazariyesine dair bazı parçalar bulunmasi ile bu tesbite halel gelmez; bak. Handbuch des Strafrechts, I, 1888, $\$ \$ 95 \mathrm{ff}$.

(18) v. Kirchmann, Die Wertlosfgkeit der Jurisprudenz als Wissenschaft, 1847. Bu bapta Sternberg, Kirchmann und seine Krịtik der Rechtswissenschaft, 1908.

(19) Nisbeten en lyi muariz yazly, Rechtswissenschaft, oder Volksbewusstsein, F. J. Stahl, 1848, yazd..

(20) Rogge, zur kritik des Rechts, 1911, s. 5. 
Roma hukukçuları körükörüne kanuna tapanlardan bişka her şeydi; Liberal, bununla beraber keyfî tarzda değil de hukukî reylerinde kanunu münasebetlerin zamuretlerine ve iyi niyete (bona fides) intibak ettirmek, onun boşluklarını ex bona ve aeque doldurmak, sertliklerini exceptio dolivi tervic ile tadil etmek suretiyle hakikaten pratik ve serbest bir kaza n̈̈ munesi vermişlerdir (21). Bunu inkâr eden kimse, belki her hangi bì neviden bir pandekt bahsi işitmiş olsa bile aslâ pandektleri bizzat anlayarak okumamış olan bir kimsedir. Instinyanus'un hukuk kitabı içinde sekillenen Roma jurisprudans'i menkulatı dahi hayata yabancı skolastiğe cebretmiyordu. Dijest'in fikralar, kanun paragraflam değildir. Böyle olduğu halde onlar böyle karşlayan kimse, onlan lekeliyor demektir. Bunu daha önceki zamanlar dahi açıça anlamıştı. Orta çă̆ın Şarihleri korpus jurisi zamanin ihtiyaçlarmı nazara almaksızın şerh etmekten cook uzak bulunuyorlardı. Bilâkis korpusun otoritesine karşı kuvvetle tașid’kJarı imana rağmen skolâstik cedel vasitalamn geniş mikyasta yardumc yaparak eski hukuk kitabm zamanın ruhuna ve icaplarına uygun surette tefsir ettiler. 17 ve 18 inci yüz yllarda usus modernus pandectarum'un ne kadar parlak olduğu umumca müsellemdir. Ancak tarihî mekteptir ki kaynaklamn bu yikssek tatbikatindan aymldı. Bu vedain sebebi bizzat o kaynaklarda değildir; tahavvül eden noktai nazarın sebebi, baska âmillerde bulunmak lâzımdır. Filhakika Romanist olmayan hukukçular, Cermanistler, Kriminalistler, usulculer ve poblisistler Romanistlerden başka bir metod mu takip etmişlerdir. Asla hayır. Şu halde tekrar eđerim ki pandektlerin bahsedilen pandektoloji ile hiç bir alıs verişi yoktur. Pandekt dersi (Pandektenvorlesung) denilen için de böyledir. Ben aksini iddia ediyorum: Doğru anlaşlan; didaktik gayesini hakkiyle göz önünde tutan pandekt dersi, bir çok bakumdan jurisprudansta mevcut olanların ilim itibariyle en serbestidir. Bunu, serbest' hukuk mesleğine salik hukukçularin en evvel itiraf etmeleri icap ederdi, Alman medenî kanunu maddelerine seri' bir nazar, bize Windscheid üslûbunda paragrafçı konstruksiyon jurisprildansı takip edilmis olan yerlerinde, pandekt hukukundan medenî kanuna intikal ile yağmurdan kaçarken doluya tutulunmuş olduğunu öğretmiş olmalıdır (22).

(21) Kipp, Geschichte der Quellen des römischen Rechts, 3 Aufl., 1909, s. 4 ff; Kiss, Archiv für Bürgerliches Recht, 1912, $214 \mathrm{ff}$; Ehrlich, Soziologie des Reehts, $1913,197$.

(22) Pandekt dersí Almanyada ilga edilmemeli idi; ve tsviçrede bu kötu misale uyulmamalı 1di, Pandekt ilmi, hukuk ilmi için, kontrapunktik musiki için, eski eserler plâstik için ne ise odur. Daha iyi bir temel mevcut değildir; pandekt dersinin tekrar ithali lehine Wenger'in mudafaas1, Das Juristische Studium, 1919 s. 5; Avusturyada muhafazası hakkinda Allgemeine Gerichtszeitung, Mauczka 1913, 442. 
Bütün bunlara rağmen bahsedilen mantıkça talil (deduktion) jurisprudansının sebepleri, göstermeğe çalışıldı̆ı ïzere romanizmde değil, bilâkis tamamiyle baska âmillerde - bilhassa meşrutî devlet hukukunun kanun mutlakiyeti inanında mündemiç olduğunu katiyetle söylemek lâam gelir.

7. Karakterize edilen ba dissünce tarzinm neticeleri knsmen iyi ve kismen de mahzurlu idiler.

a) Memnuniyet verici neticeleri: Zamana uygun ve kismen de hakikaten mïmtaz kanunlar vüicuda getirilmekle (Alman poliçeler kanunu, Alman ticaret kanunu, Saksonya medenî kanunu, tsviçre borçlar kanunu, Alman iflâs kanunu, Avusturya hukuk usuliu kanununu düşünelim) hukuk ilmine ve hukukî kazaya o vakta kadar galip surette hâkim olan örf ve âdet hukukundan daha itimada sayan bir esas konulmuştu. $\mathrm{Bu}$ suretle hukuk daha vazih ve daha kabili ihata oldu.

Hâkimin mesaisi de mühim surette kolaylaşmı oluyordu. Mutlak surette kanuna itaatkâr kazadan daha elverişli ve daha kullanışl bir ada let yoktur; hiç olmazsa kanun da iyi olursa. Hâkim yalnuzca kanunu iyi tanjr ve onun içinden güzelce çlkmağı bildiği takdirde vazifesini yapmı olurdu. Bưnun dışında millâhazalar yürütmeğe muhtaç değildi. Kanun koyucu, o büyuik sosyolog hâkim için lâzım geleni đüşünmüştür. Bu, bir çoklarının kolay, açık bulduğu bir mesai taksimidir.

Başka bir fayda đa hâkimin yanimasımın ve indî hareketinin mïmkün olduğ kadar bertaraf edilmesinden ibarettir. Yularda sevk edilen at doğru yolda gider ve yolundan çlkmaz. Açık yazlmıs bir kanunda isti datsz bir hakim dahi emin bir rehber, ateşin mizaçlı bir hakim de sabit bir 'sınr bulmuştur.

b) Fakat bu faydalara - hakikaten mevcut iseler - mukabil daha galip zararlar ve mahzuriar görülimïştür.

Hâkimin fonksiyonu sirf bir fikriliğe tenezzül etti. Hâkim - ve mut lak surette hukukçu - tatbik (Subsumtion) ve talil makinesi halini almişt. Neticenin hakh ve nusfata uygun olup olmadiğ sorulmaz, surf kanuna muvafık olup olmadığı aranird. Kanun sert. olsa da iyi bir hâkimlik ancak onu gayretle tutmaktan ibaret idi. Bu suretle kaza, bir dimağ mesaisi içinde donup kalmak kalb ve ruh ise kaybolmak tehlikesine diusstiu. Şekilcilik ve skolâstik içinde körleşip katılaşmağa mahkûm oldu. Sứ terkipler ve zarif taliller, prensip itibariyle semereli neticelerden daha muteber saynld.

Bütün bunlar, hâkimin karakteri onun şahsiyetì ve hakikî kưreti hakkmida ağır bir tehlike idi. Bir çocuk gibi adım adım yedilme ifade eden 
bu kanuni sistem ile hâkim - vasatî halden bahsediyorum - istiklâlinden ve kudretinden çok kaybetmiştir. Her adımi kendisine tehlikeli gösterilen, bizzat serbestçe karar ittihaz edebilmesi menedilen ve tahdit olunan kimse nihayet fikir zayflığına uğrar. Teşebbüs hassasını, karar kabjliyetini, cesaretini kaybeder. Cesaretsiz, suinepe bir allâme, bir borukrat olur ve gitgide $\mathrm{F}$ şeması üzerine çalışmağı itiyat edinir. Kendisine gayri reşit muamelesi edilen kimsenin, fiilen gayri reşit olmak ve o suretle hareket etmek büyük tehlikesi içinde yüzeceği hakkındaki eski hakikat yeniden yeniye teeyyüid eder (23).

Fakat daha bijyük bir tehlike vardı. Birer birer şekil verilmis, ekseriya pèk kazuistik bir kanuna korkakça tebeiyyet kanunu tatbik edenin aslen meveut hukuki hissini yavaş yavaş körleştirmeğe sebep olur. Hâkim karamnın, bir istintaç yolu ile kanundan çkamlabilir olduğunu kâfi görür ve bununla iktifaya mecbur olursa o hâkím, kararının özï itibariyle mesruiyeti meselesinde kendi adalet vicdani huzurunda mesul olabilmek hususundaki ince hissini kaybeder. Adalet işinde hukukî hissin tazyik ve imhası kadar kötü hiç bir gaey yoktur (24).

Bununla beraber hiç bir şey kendini imha ettirmez. Tabiati rüzgârla savuralım: o gene avdet eder ve ebedi hakkını iddia eder ve bu, doğru yolda olmasa bile dolambaçlı yolda olur. Kanuna tabi hâkimde de böyle olmuştur. Bir kaide çok sıkı olursa ondan kurtulmağa eğri yollarda çare aranır. $\mathrm{Bu}$, terbiye bakımmdan caridir, askeri ve idari hizmette kendini gösterir; fakat adalet tevzii işinde de isbatlar vardur. Bir çok, hatta en iyi ve vicdanen ince hâkimler, kanun yğınlarını korkunç bir zincir ve ağır bir vicdan tazyiki gibi hissetmişlerdir. Oyle bir zincir ki ekseriya doğru ve meşru neticeler elde edilmesini menetmiştir ve böylece kaçamakh ve hileli yollara düşmüşlerdir. Bir yeni kalem mücadelesinin Kryptosozyoloji dediği metod meydana gelmiştir. Yanls zannettiğim bu tabire itiraz etmek istemiyorum; hâdise budur. Hâkim, evvel emirde kendi hukukî́ hissini yoklar ve kendisine doğru görünen neticeyi bulur; bundan sonradır ki kanuna müracaat eder. Kanun bu karara uygun ise ne âlâ. Fakat uygun düşmezse - kanun serbest surette tefsir edilmez, yahut bir bosluk tesbit edilmez, hele kanun hilâfina bir hüküm verilmez; bu, isyan ve hukuktan inhiraf olacaktır! - Bilâkis bizzat hâdise, hukukî unsur, kabul ve ittihaz olunan karar kanundan glkma bir kararmıs gibi tezahür edinceye kadar slkilır ve

(23) tsabetli olarak F. W. Foerster, Staatsbürgerliche Erziehung(2), 1914, s. 66 ve Śiddeutsche Monatschefte, 1914, 249 ff. Bak., Stampe, Freirechtsbewegung, 1911, s. 15, 29.

(24) Bak. Kirchmann, s. 6, Spiegel, Gesetz und Recht, 1913, s. 69. 
evrilip çevrilir. - Böyle bir muameleye mantıkta Sophisma deler; fakat etikte burada, cizvitlerin gaye vasıtayı mukaddes kılar suretindeki ahlâkma müracaat oluna gelmektedir (25).

Tenvir için kısmen pek malûm olan bir kaç misal verelim.

Alman hukuk yargllama usulü, muhakemenin sifahiliğini emreder; bu şifahi muhakemeye lâyihalarla hazirlanılır. Haydi buna göz yumalım. Bir cok avukatlar muhakemede sadece lâyihalar okumakla iktifa ederler. Bunun şifahi "muhakeme" nin bir komedyası olduğunda şüphe yoktur. Fakat bazı buiyiuk sehirlerde avukatlar lâyihalannın, istinat edilen senetlerin mahkemede sözle izah edilmiş, okunmuş addedilmesini mahkemeden rica ile iktifa ederek sifahi muhakeme düpedüz yalandan olur; bunun üzerine keyfiyet celse zabıtnamesine işaret edilir, şifahi muhakeme cereyan etmiş sayılır. Bu, hakikat hilâfı bir iştir (26). - Bir ilk derece mahkemesinin hükmünde - bir kaç yüz sahife tutan - esas dosyanm bütün mündericatının şöyle şöyle mahkeme hukuzunda takrir edilmiş olduğu yazılmıştı. Istinaf hakimi bu tesbitin "açlkça inanllmaz" bir şey olduğunu beyan etti. - Bir Alman şehrinde kaba saba bir hâkim vard, bir çok memuriyet arkadaşları onu hakikî halkȩı bir hâkimin timsali sayıorlardı. Bir gün yeni referandarlamṇ şu sözlerle selâmlad. "Sizler çok okumuş baylar olacaksınız. Şüphesiz ceza muhakeme usulü kanununu ezber, yutmuş gibi bilirsiniz. Böyle bir okumuşluk karşısmda size bir faydam olmayacaktır. Fakat benden iki şey öğrenebilirsiniz. Birkere usul kanununa göre hareketten daha iyi ne yaplabilir. Ikincisi tahkikatımm usul kanununa uyar olması için bir protokolun nasıl hazırlanacağıdır". - Bir șimendifer, bacasından çkan kıvicımlarla bir zarar iras etmiş idi. Müesseseye ve müstahdemlerine hiç bir kusur isnat edilemiyordu. Mutazarrırın, za. rarina karşı bir tazminat alması hak ve adle uygun idi. Fakat o vakit henuiz bu yolda mesuliyet için bir kanun yoktu ve mer'i kanun tazminatı, yalnz zarar ika eden kimsenin kusuru halinde tanıyordu. Böyle bir halde haklı bir hüküm vermek için Baviyaralı hâkim ne yapmıştı? Şöyle basit bir kaide koydu. Müessese, kusurlu olarak hareket etmiştir, çünkü bir şimendifer işletme Akilya kanununca bir kusurdur. Bu sebepten dolayı şimendifer idaresi mahkûm edilmiştir. Hükmün hakikî sebebi șüphesiz tamamen başka idi; uydurma sebebe ise (ki kusurdur), hükmüi veren hâkim de bizzat gụ̧̈ inanmıştır.

(Devam edecek)

(25) Bak. Stampe, Freirechtshewegung, 1911, s. 19 ff; Wildhagen, Reisserfestschrift 1913, 356.

(26) Bak. Beradt, der Richter, s. 67. 